\title{
The History of Scottish English and A Brief Description of the Salient Linguistic Features That Characterize The Scots Dialect
}

\author{
Azhar A. Alkazwini \\ The Public Authority of Applied Education (PAAET), Kuwait \\ Email: aasalkb@hotmail.com
}

Received: 13-10-2016

Published: 01-05-2017
Accepted: 02-01-2017

doi:10.7575/aiac.ijalel.v.6n.3p.81
Advance Access Published: March 2017

URL: http://dx.doi.org/10.7575/aiac.ijalel.v.6n.3p.81

\begin{abstract}
A brief history of the Scots dialect shall be presented, and, the salient Linguistic Features that characterize Scots shall be discussed. Some observers have different views regarding these linguistic features. I shall provide examples of these differences and conclude with the fact that the Great Vowel Shift played a major role in forming Scots and, as a result, Scots has its own characteristics that distinguishes it from other dialects.
\end{abstract}

Keywords: English Language, Variation, History of English, Salient Linguistic Features, Scots Dialect

\section{The History of Scottish English}

The history of Scotland and its language goes hand in hand with the history of the British Isles in general. It in many ways demonstrates a very similar pattern of development as far as the major historic events and social changes are concerned. Important events of the past such as the Roman, Scandinavian and Norman invasions, industrialization, the World Wars, etc. formed very similar conditions for England, Scotland and Ireland. The basic linguistic features of all the three systems dependents on the fact of them belonging to the Indo-European language family and Germanic group. The further development was so closely interconnected because of political, cultural, social and educational links. Nowadays, it is not easy to draw the exact borderline when dealing with the nature of borrowings and language shifts. Another common feature is the dialect discontinuity that exists in all three countries mentioned alongside the standardized variant.

In Scotland, Gaelic serves as the standard. Gaelic belongs to the Celtic branch of the Indo-European language family. Crystal describes two distinct groups: British Celtic and Irish Celtic (Crystal 2003:302). These groups existed at the moment when the Roman invasion started, but it is hard to say whether these groups had been formed on the British Isles or had they existed before the Germanic tribes left Europe and crossed the Channel. Modern Gaelic, Irish and Manx descended from the Irish Celtic group (Crystal 2003; Glaser 2007; MacKinnon 2010; McLennan 1998; Millar 2007).

Some Scholars think that Irish and Scottish Gaelic may have arisen from the 10th century onwards, and perhaps even earlier (Crystal 2003:302; Glaser 2007:61-62; Macleod 2010:22). "Mutual understanding was durably secured by the fact that a distinct literary variety, Classical Common Gaelic, enjoyed recognition on both sides of the North Channel until the 17th century" (Glaser 2007, p.61). Irish and Scottish Gaelic used to have a number of "peripheral" varieties that were characterized by a "tendency to preserve archaic forms of the language" and now almost extinct.

Through its long history, Scottish Gaelic exposed to some conditions that resulted in language shift. These conditions caused the language to adopt features of other linguistic systems in contact. There are three variables that influence the process of language shift: The External setting, the Speech behavior and the Structural consequences (Millar 2007:103).

In the sixth century, Scotland experienced the introduction of Insular West Germanic speech. This came in two phases. Both the Northern dialect of England and its Scottish form derived from Northumbrian Old English, but then developed independently and became the official language of the nation.

Two speech forms developed within Scotland. They both stemmed from Old English. The terms 'Scots' and 'Scottish English' are used to differentiate between them. Unlike other Old English derived speech forms, Scots is not considered a dialect of English, yet a distinct language. It is considered as part of 'English' in the pure linguistic sense. 'Scottish English', on the other hand, is a form of English (McClure, 1994:23).

In the ninth century, Gaelic became the main language in the North of Scotland. It was beginning to evolve its own Scottish form of the language. In 1494, Gaelic was replaced by 'Scots', and it was a result of political development 
(Baoill, 2010:13). A standard 'Scots' is presumed to date back to the 14th century (Glaser 2007:79; Macleod 2010:23). By the middle of the 14th century, a form such as 'Inglis' appeared. Inglis was widely spoken in Lowland Scotland.

\section{The Salient Linguistic Features}

\subsection{Phonology}

\subsubsection{Consonants}

Over the past 200 years, little has changed in Scots with regard to consonantal alternations and innovations. There is a small number of significant changes that are distinct from the general changes that took place in the history of English.

\subsubsection{The Lateral Sonorant [1]}

Eighteenth century Scots commentators rarely seem to differentiate between fronted and retracted [1] sounds; 'bright' and 'dark' /1/. Murray (1984), a nineteenth century observer gives little attention to the social, historical or regional differences.

Social distinctions are clear in modern language. In Edinburgh speakers, prestige speech is distinguishable by their use of front forms, while the speech of the working class is marked by their retracted laterals (Johnston, 1983:23-25).

In Scots phonology, the effacement of syllable-final lateral sonorants is a common and historical recurrent feature. "When coalescing consonants preserve the long, or broad sound of preceding vowels, then the vowel is changed, or the double consonant vanishes or receives the guttural sound, if combination admit it" (Adams 1799, p.152-3).

\subsubsection{2/r/ Segments}

This is frequently described as the 'harsh guttural' (Jones, 1997:320). Wilsons' (1915) statement regarding /r/ segment that it is "pronounced in Scottish differently from English $r$, being always given a distinct trill, whether at the beginning or end of a word, and it does not, as often in English, alter the pronunciation of a preceding vowel sound" (p.16). From records of the eighteenth and nineteenth centuries, Scots is identified as being rhotic, with the loss of syllable-final [r] being recorded only now and again. It is traditionally known that Scots would either pronounce [r] with a tap or a trill, regardless of where it occurs in a word (Johnston 1997:510).

One of the most salient consonantal alternations is changing obstruency value (Jones 1997:325). There is a confusion that Scots face when using $d$ and voiced th. They pronounce adder, bladder with an intervocalic voiced dental fricative, where in bother, worthy they would use a voiced dental obstruent (Jones 1997:326; Elphinston 1787:26).

\subsubsection{Fricativising and Voicing Contrasts}

There is evidence that Scots tend to reduce the 'vocality of the palatal vowel' in words that contain -ium' (Jones 1997:322). Words such as medium, genius are pronounced as meed-yum, geen-yus. There is also historical evidence that Scots consists of an [p]/[f] alternation. "Inglish gahp, flap and skip become Scotich gahph, flaf and skif" (Jones 1997:326; Elphinston 1787:26).

\subsubsection{Cluster Simplification}

The decreasing of use of syllable-initial [k] and [g] segments in [kn] and [gn] clusters in Scots continued through the eighteenth and nineteenth centuries. Jones (1997) notes that older Scots still pronounce 'K' when followed by ' $N$ ' in words such $k^{\prime} n e y f e, k^{\prime}$ nowe, but this is no longer taught in schools and has resulted in the newer generations dropping it (Jones 1997; Murray 1873).

\subsubsection{Glottalisation}

"A very common change in British dialects is the reinforcement or replacing of voiceless stops in coda position by glottal stop, especially of words syllable final / $t$ /, or syllable final / $t /$ before a syllabic nasal. Glottaling can happen to $/ \mathrm{p}, \mathrm{k} /$ in these positions and affect all stops intervocalically and in intervocalic clusters" (Johnston 1997, p.500). The glottalisation of syllable-final voiceless obstruents appears to have come into effect in the twentieth century. There is little evidence of it in the eighteenth or nineteenth centuries. In recent studies, Macaulay and Trevelyan (1977) show that glottalisation is more common in pre-pausal environments, and varies with phonetic context in the discourse.

\subsubsection{The $/ \mathrm{m} /, \mathrm{w} / \mathrm{w} /$ Alternation}

This alternation is common in the Scots of the eighteenth and nineteenth century (Jones, 1997:330). Scots tend to use

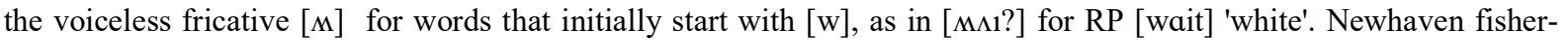
folk often drop the sound $h$ before $w$ in words such as wun 'when', wut 'what', wup 'whip' and wuskay 'whisky' (Wilson, 1926:19).

\subsubsection{Vowels}

The length of vowels in Scots is an important feature. Millar carried out a comparative analysis based on his work and the work of Wells (1982). Table 1 shows the results of his analysis. He believes that all Scots dialects have four phonemic diphthongs: CHOICE, OWER, BITE and TRY. 


\begin{tabular}{|c|c|c|}
\hline SSE & Scots dialects & Wells (1982) \\
\hline $\mathrm{N} / \mathrm{E}$ & BUIT & $\mathrm{N} / \mathrm{E}$ \\
\hline MEET/BEAT & MEET/BEAT & FLEECE \\
\hline MATE/BAIT & MATE-HAME/BAIT & FACE \\
\hline DRESS & DRESS & DRESS \\
\hline TRAP & TRAP & TRAP/BATH/PALM/START \\
\hline KIT & KIT & KIT \\
\hline STRUT & STRUT & STRUT \\
\hline BOOT & OOT & FOOT/GOOSE/CURE \\
\hline \multirow[t]{2}{*}{ GOAT } & GOAT & GOAT \\
\hline & CAUGHT & THOUGHT/NORTH \\
\hline CAUGHT/COT & $\mathrm{COT}$ & LOT/CLOTH \\
\hline OUT & OWER & MOUTH \\
\hline BITE & BITE & \\
\hline TRY & TRY & PRICE \\
\hline CHOICE & CHOICE & CHOICE \\
\hline
\end{tabular}

(McColl Millar 2007:21-22)

In the last quarter of the eighteenth century and into the nineteenth century, there have been six major salient features with regards to Scots pronunciation, some of which have survived into modern language. The alternations appear to be between $[\mathrm{a}] /[\varepsilon],[\varepsilon] /[\mathrm{]}],[\mathrm{j}] /[\mathrm{o}],[\varepsilon] /[\mathrm{i}],[\mathrm{e}] /[\mathrm{a}]$ and $[\mathrm{i}] /[\mathrm{ai}]$, the last of which are a form of the Great Vowel Shift (Jones 1989: 281-94).

The other five alternations seem to represent high contrasts similar to those associated with the Great Vowel Shift, although they are shorter in length. Eighteenth and nineteenth century observers would use the terms 'long' and 'short' not only in terms of the durational characteristics of the vowels. 'Long/short syllable', likewise, would have had little relation to the durational phenomena.

\subsubsection{Low and Mid Vowel Alternation and Mergers}

\section{a) The $[\mathbf{e}] /[a]$ Merger}

The use of 'polite' Scots in the eighteenth century was characterised by raised (palatalised) versions of front vowels, both long and short, although there is some ambiguity about the social consequences of this $[\mathrm{a}] /[\mathrm{e}]$ merger. Words such as make, take, brake and apple in Scots are pronounced with the [a] vowel; mak, tak, brak and apel (Jones 1997:294). There is no open lengthening of preceding vowel. They descend from short vowels. Scots lengthen the vowel (either monothong or diphthong), stress shift backward and drop the final vowel.

\section{b) The $[a] /[\varepsilon]$ Merger}

Evidence from this period suggests that the [a] vowel was constrained to an $[\varepsilon]$ vowel. Words that consist of a short open [a] vowel were pronounced with a 'slender a', as in cattle/ kettle, vassal/vessel, ketch/catch, black/ bleck, lamb/ lemb and hand/ hend (Jones 1997:296).

\section{c) The $[\varepsilon] /[i]$ Merger}

In Eighteenth century Scots, the mid vowel [i] was considered a stigmatised feature and was regarded as a regional variant. Scots would pronounce mare, blaze, complain, bacon and chair, as mere, bleze, compleen, beckon and cheer. This salient feature of Scots' short [ $\varepsilon]$ to [i] is also clear in beast/best, bread/breed/bred and dread/dryed (Jones 1997:299). Vowels are long because of the phonological root. The long and short vowels are not phonemically distinctive.

\subsubsection{Lowering and Centring of High Front Vowels}

An important feature that was observed in the eighteenth century was the tendency to recognise front high stressed vowels ([i] and [1]) as lower and central segments. Bill/bell/bull, treble/trouble/triple and sin/sons/sun are incidents where the front high vowels are lowered and centralised (Jones, 1997:300). This lowering and cantering of the stressed front high vowels resulted in a more central [i] or sometimes [ə] (an unrounded mid central vowel), but there is no recorded data that enables us to know the exact phonetic description of this alternation. 
This merger (high/low mid back) vowels is regarded as an overtly Scots feature of pronunciation. This alternation is related to the 'boat' vowel. Scots use $<\mathrm{oa}>$ for words that consist of the [ $\mathrm{\jmath}]$ vowel. Words such as polish, proper, and not are produced as poalesh, proaper, and noat. (Jones 1997:302-304).

\subsubsection{The Diphthongs}

\subsubsection{The $[\mathrm{au}] /[\mathrm{u}]$ Alternation}

The labial vowels fail to diphthongize in the Scots form of the Great Vowel shift. The Scots [hüs]/[haus] alternation is the features that has been most commented on with relations to the British English Phonological phenomena (Wells, 1982). Despite the fact that none of the North dialects have this feature, Scots does. It is the "put/cup" Split (Beal, 1996:371). Wells (1982: 356) call this feature "the absence of a FOOT - STRUT split". It is Middle English /u:/ failing to diphthongise. There have been many explanations that suggest reasons for this failure. One of the reasons is related to the Great Vowel shift. The new low segments entered the phonological system and caused all the other vowels to raise. This process prevented vowels from merging. One argument is that the high vowels needed to diphthongise to prevent them from merging with lower segments. High mid back vowels such as [oo] in Northern Middle English did not undergo this raising. The segment did centre to [ææ] and [øø]. This was the result of 'no raising- no diphthongisation' (Lass 1984: 126ff; Jespersen 1949; Labov 1994:115-54).

There are recordings in the eighteenth and nineteenth century of the Scots 'undipthongised' forms. There is a difference in pronunciation, with regards to $[\Lambda \mathrm{u}]$ shapes, between Central Scottish and Southern Scots (Murray 1873:117). "The Central Scottish soo, doo, hoo, yoo, foo, moo are in the South [of Scotland], saw, duw, huw, yuw, fuw, nuw" (Jones 1997, p.309). Murray believes that there is a difference in the diphthong when it does not 'arise' from the Great Vowel Shift. It raised thorough other ways such as [1]-vocalisation, or pre-[r] Breaking. The undiphthongised forms are believed to have low prestige status in present day, and evidence of this is stated in The Spelling-Book upon a New Plan (Anon 1796). There is also evidence that suggests that the non-diphthongal forms were prestigious. This was clear in some Scottish sociophonetic texts (Jones 1997:310).

Several studies have been carried out on the distribution of the $[\mathrm{au}] /[\mathrm{u}]$ alternation in modern Scots (Macaulay and Trevelyan 1977; Macaulay 1991).

\subsubsection{The [ai]/[ii] Alternation}

As a result of the Great Vowel Shift, some grammatical and orthoepistic Scottish sources dating from the eighteenth century show that high front palatal [i] type vowels do not appear as diphthongs. Rather, [ai] diphthong would be produced by Scots speakers of that period. A standard metropolitan dialect would use [ii]. The vowel shift diphthongising mechanism would act upon long high front vowels. So words such as rip and sip are 'Scottishly' ripe and sipe.

Both, stressed vowel and diphthongal length and quality are affected by the Scots Vowel Length Rule, "Aitkin's Law". The rule of Scots Vowel Length is that vowels are lengthened before voiced fricatives $(s, z)$, before $[\mathrm{r}]$ and word boundaries. This causes the first element to lengthen as in rise, ties, tie. However, before voiced obstruents and [1], a

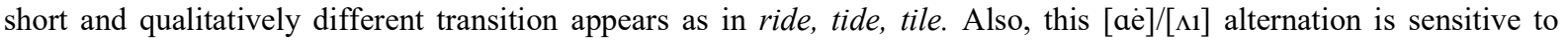
morpheme and word boundary contexts. Examples are [ $\left.{ }^{\mathrm{t}^{\mathrm{h}}} \mathrm{aed}\right] /\left[\mathrm{t}^{\mathrm{h}} \Lambda 1 \mathrm{~d}\right]$ tied/tide (Jones 1997:314; Aitken 1981). The Scots Vowel Length Rule is not always adhered to by speakers, and thus we must not accept it unquestioningly (Jones 1997:315). A similar increase in vowel duration, according to Lodge (1984:88) and reflected in his data, might just as readily happen in non-'Aitkin's Law' contexts; [`aat aaksent] 'that accent'.

\subsection{Syntax}

\subsubsection{Noun Phrase}

\subsubsection{Relative Clauses}

Scots use Wh- forms but in an ungrammatical way. "Do you know who you speak to. whom. Scots and vulg. Eng. Who is often used ungrammatically for whom" (Beal 1997, p.358). Tulloch (1980:276) argues that Scotts uses wh- forms to signal that the speech has some degree of formality. By the nineteenth century, these forms had infiltrated Scots further. It moved from written usage to the more formal end of the spectrum of spoken usage (Beal 1997; Baettie 1787).

\subsubsection{Use of the Definite Article}

"A well-known characteristic of Scottish English is the use of the with nouns denoting institutions, certain illnesses, certain periods of time and with quantifiers such as both and all" (Miller 1993, p.128). Some examples of Scots' use of definite article are the day 'today' and the now 'just now'. This use was most common in the eighteenth century and is still used in present-day Scots, although not to the extent Miller believes. In Standard English, the definite article is not used in this way. Macaulay (1977) found that while all classes use the definite article in some ways, other ways were restricted only to low-class speech.

\subsubsection{Use of Possessive Pronouns}

The use of possessive pronouns in Scots is linked to the use of the definite article (Beal 1997:362). This is not the case in Standard English, where neither pronoun nor article would be used. The use of the possessive by Scots as "Scotticism" was noted by Beattie (1787:57) and Mitchell (1799:56) but Murray (1873) does not mention it. This could 
suggest that he does not recognise it as a Scotticism. Macaulay (1991:71) found this use of possessive pronouns only in lower-class speech. This contradicts Aitken (1979:106) in that it is a "covert Scotticism". A couple examples of Scots' use of possessive pronouns are we were in for wer lunch and I'm away to my bed.

\subsubsection{Order of Direct and Indirect Object}

The placing of the indirect object pronoun before the direct object is another syntactic feature noted by Beattie (1787) and Mitchell (1799). "The order of pronominal objects, direct and indirect, when used consecutively, often differs in Sc. from St., the direct object coming first" (Grant and Dixon 1921, p.98). An example of this feature is clear in give me it.

\subsubsection{Verb Phrase}

\subsubsection{Modal Verbs}

The use of modal verbs in Scottish English differs considerably from Standard English (Miller 1993:116). The 'Double Modal' construction has been ungrammatical in Standard English since the early Modern period (Beal 1997:368). "The Scots are more apt to misapply will than shall, especially in the first person singular and plural" (Beattie 1787, p.111). The absence of 'shall' and 'should' from Scots is what Beattie and Sinclair (1782:76) refer to. Scots tend to use the first modal to state possibility and probability, and the second modal is the root which implies ability and permission. Although Aitken and Miller (1993:116) note evidence that 'shall' is a feature of Scots, it is now no longer distinctively Scots. It has become commonly used in other dialects of English.

\subsubsection{Negation}

The use of 'no' in negation, as opposed to English 'not', is included in lists of Scotticisms (Beal 1997:370). "No is sometimes used for not" (Sinclair 1782, p.136). Murray (1873) points out the construction is the "negative emphatic", "a strong negation of a statement, formed in auxiliaries by the full form with the adverb no or not" (p.216). Multiple negation is another feature noted as Scotticism (Beal 1997). Some examples of the use of negation are I cannot walk no further and I cannot eat no more.

\subsubsection{Discourse Features}

In Scots, two of the most salient discourse markers are (you) see and (you) ken, A Scots lexical item of ancient pedigree, (you) 'ken' is characteristic of the urban vernacular and is stigmatized (Beal 1997:375).

\subsection{Lexis}

"The recorded vocabulary of Scots is extraordinary large and diverse" (McClure 1994 ,p.74). Scots and British English vocabulary are closely inter-connected. Over the last three centuries, spoken Scots has been characterized as an informal language as it is not used officially (Tulloch 1997:380). Some believe that Scots is disappearing, but Aitken (1981:80) does not share that view. Rather, he sees this is a period of creativity.

The Scots vocabulary consists of large amounts of loan words from different languages. The largest source of loanwords from Celtic languages is Scottish Gaelic. Examples of borrowed Gaelic words are caird, clachan, messan, raith and tocher. Some words that travelers used are; fillebag, claymore, and sporran. Kailie 'gossiping' was borrowed in the 19th century. It is derived from gille 'a lad' which was also derived from gillie. It has now developed the meaning of a 'sportsman's attendant'. There is a number of words borrowed from Romany; barrie 'an adjective to express a strong state of approval', chore 'to steal' and gadgie 'a man'. Although Scots borrowed extensively from Latin in earlier periods, the amount of loans in the last couple of centuries have been less, and particularly in the domain of law and court. French, Scandinavian Languages and Dutch all played a part in Scots lexis (Tulloch 1997:387).

\subsubsection{Formation of New words}

Scots has a special status, insofar as it is a widely used literary and spoken language with no agreed standard vocabulary. It has no dictionary of contemporary usage, so there was scope for the expansion of vocabulary by many means. They were able to add to the meaning of existing words. There are many different kinds of words that have been 'invented' such as compounds, derivations (adding affixes to existing words) and blends (bringing together two separate words as one new word) (Tulloch 1997:397). Some of these words are galdroch 'greedy', Galliceer 'Highlander', gallion 'lean horse', gally-gander 'a fight with knives', garhashloch 'wet, windy and cold' and skintie (a blend of the two words skimpy and scanty). Most of the compounds apply to a broad sphere of life and include activities, emotions and attitudes (Waddell 1871:78).

\section{Conclusion}

With regards to the major historic events and social changes stated in this paper, the history of Scottish English shows a very similar development pattern to that of the British Isles. Some important events such as the Roman, Scandinavian and Norman invasions, and other events formed very similar environments for England, Ireland and Scotland. The basic linguistic features dependent on the fact that all three systems belonged to the Indo-European language family and Germanic group. The further development was so closely interconnected because of political, cultural, social and educational links. As for that, Scots dialect has many linguistic features that distinguishes it from any other dialect. One fact is that change of social and cultural environment, close contacts with other systems has not but resulted in linguistic changes. There are different views regarding these changes, as previously discussed, one of which is the role of the Great Vowel Shift and its effect on Scots. 


\section{References}

Adams, J. (1799). The pronunciation of the English Language Vindicated from Imputed Anomaly and Caprice. Edinburgh: English Linguistics 1500-1800, 72. R. C. Alston (1968) (Edt.). Menston: Scolar Press.

Aitken, A. J. (1979). Scottish Speech: A historical view with special reference to the standard English of Scotland. A. J. Aitken and T. McArthur (Eds.). Language of Scotland. Edinburgh: Chambers. p.85-118.

Aitken, A. J. (1981). The Scottish vowel-length rule. So Meny People, Longages and Tonges: Philological Essay in Scots ana Medieval English Presented to Angus McIntosh. M. Benskin and M. L. Samuels (Eds.). Edinburgh: Edinburgh University Press.

Anon. (1796). The Instructor: or An Introduction to reading and Spelling. London.

Baoill, C. (1997). The Edinburgh History of the Scots Language: The Scots- Gaelic Interface. Charles Jones (Ed.). Edinburgh University Press. Chapter 13. p. 551-568.

Baoill, Colm (2010). The Edinburgh Companion to the Gaelic Language: A History of Gaelic to 1800. Watson, M. and Macleod, M. (Eds.). Edinburgh: Edinburgh University Press. p.02- p.21.

Beal, J. (1996). The Jocks and the Geordies: Modified Standards in Eighteenth Century Pronouncing Dictionaries. English Historical Linguistics 1994: Papers from the 8th International Conference on English Historical Linguistics (8. ICEHL, Edinburgh, 19-23 September 1994). Britton, D. (Ed.). Amsterdam : J. Benjamins.

Beal, J. (1997). The Edinburgh History of the Scots Language: Syntax and Morphology. Charles Jones (Ed.). Edinburgh University Press. Chapter 9, p.335- 377.

Beattie, J (1787). Scoticisms Arranged in Alphabetical Order. Edinburgh.

Crystal, D. (2003). The Cambridge Encyclopedia of the English language. New York: Cambridge University Press.

Elphinston, J. (1786, 1787). Propriety Ascertained in her picture, or Inglish Speech and Spelling Rendered Mutual Guides, Secure Alike from Distant, and from Domestic, Error. 2 Vols. London.

Glaser, K. (2007). Minority Languages and Cultural Diversity in Europe: Gaelic and Sorbian. Linguistic Diversity and Language Rights, 3. Clevedon, Buffalo, Toronto, Multilingual Matters Ltd.

Grant, W. and J. Dixon, M. (1921). Manual of Modern Scots. Cambridge: Cambridge University Press.

Jespersen, O. (1949). A Modern English Grammar on Historical Principles. Heidelberg: Carl Winters.

Johnston, P. A. (1983). Irregular style variation patterns in Edinburgh speech. Scottish Language, 2. p. 1-19.

Johnston, P. (1997). Regional Variation. In Jones, C. (Ed). The Edinburgh History of the Scots Language. Edinburgh University Press. Chapter 11, p. 433-513.

Jones, C. (1989). A History of English Phonology. London: Longman.

Jones, C. (1997). Phonology. In Jones, C. (Ed). The Edinburgh History of the Scots Language. Edinburgh University Press. Chapter 8, p. 267-334.

Labov, W. (1994). Principles of Linguistic Change: Internal Factors. Oxford: Blackwell.

Lass, R. (1984). Phonology: An introduction to Basic Concepts. Cambridge: Cambridge University Press.

Lodge, K. R. (1984). Studies in the Phonology of Colloquial English. London: Croom Helm.

Macaulay, R. K. S. and Trevelyan, G. D. (1977). Language, Social Class and Education. A Glasgow Study. Edinburgh: Edinburgh university Press.

Macaulay, R. K. S. (1991). Locating Dialect in Discourse: The Language of Honest Men and Bonny Lasses in Ayr. Oxford: Oxford University Press.

MacKinnon, K (2010). The Gaelic Language-Group: Demography, Language-Usage, Transmission, and Shift. The Edinburgh Companion to the Gaelic Language. Edinburgh: Edinburgh University Press Ltd. p.128-145.

Macleod, M (2010). Language in Society: 1800 to the Modern Day. The Edinburgh Companion to the Gaelic Language. Edinburgh: Edinburgh University Press Ltd. p. 22-45.

McClure, J. (1994). The Cambridge History of the English Language. Hogg, R., Blake, N., Burchfield, R., Romaine, S. and Lass, R. (Eds.). English in Britain and overseas: Origins and Development. Vol.V. Bruchfield, R. (Ed.). Cambridge: Cambridge University Press.

McClure, J. D. (1994). 'English in Scotland', in R. Burchfield (Ed.) The Cambridge History of the English Language. Vol. 5, English in Britian and Overseas: Origins and Development. Cambridge: Cambridge University Press. p.23-93

McLennan, G. (1998.) Scots Gaelic: A Brief Introduction. Argyll Publishing: Glasgow.

Miller, J. (1993). The Grammar of Scottish English. J. Milroy and L. Milroy (Eds). Real English: The Grammar of English Dialects in the British Isles. Harlow: Longman. p.99-138.

Millar, R. (2007). Northern and Insular Scots. Edinburgh: Edinburgh University Press Ltd.

Mitchell, H. (1799). Scotticisim, Vulgar Anglicisms and Grammatical Improprieties Corrected. Glasgow. 
Murray, J. A. H. (1873). The Dialect of the Southern Countries of Scotland. The Philological Society: London.

Murray, J. and Morrison, C. (1984). Bilingual Primary Education in the Western Isles. Scotland: Report of the Bilingual Education Project 1975-81. Storoway: Acair.

Sinclair, J. (1782). Observation on the Scottish Dialect. Edinburgh.

Tulloch, G. (1980). The Language of Walter Scott: A Study of his Scottish and Period Language. London: Ande Deutsch.

Tulloch, G. (1997). Lexis. In Jones, C. (Ed). The Edinburgh History of the Scots Language. Edinburgh University Press. Chapter 10, p. 378-432.

Waddell, P. H. (1871). The Psalms frae Hebrew intil Scottis. Edinburgh: Menzies.

Wells, J. C. (1982). Accents of English. Vol.3. Cambridge: Cambridge University Press.

Wilson, J. (1915). Lowland Scotch, as Spoken in the Lower Strathearn District of Perthshire. London: Oxford University Press.

Wilson, J. (1926). The Dialects of Central Scotland. Oxford: Oxford University Press. 